BEFORE OUR EYES 
Princeton Series of Contemporary Poets

Susan Stewart, series editor

For other titles in the Princeton Series of Contemporary Poets see page 213 


\section{BEFORE OUR EYES}

New and Selected Poems, 1975-2017

\section{Eleanor Wilner}

Princeton University Press

Princeton \& Oxford 
Copyright (C) 2019 by Eleanor Wilner

Requests for permission to reproduce material from this work

should be sent to permissions@press.princeton.edu

Published by Princeton University Press

41 William Street, Princeton, New Jersey 08540

6 Oxford Street, Woodstock, Oxfordshire OX20 1TR

press.princeton.edu

All Rights Reserved

Library of Congress Control Number: 2018965561

ISBN: 978-0-691-19332-8

ISBN (pbk.): 978-0-691-19333-5

British Library Cataloging-in-Publication Data is available

"Everything Is Starting," "Field of Vision," "What Narcissus Gave the Lake," "Moon Gathering," "This Straw and Manure World," "Just-So Story," "Found in the Free Library," "The Girl with Bees in Her Hair," "Be Careful What You Remember," and "Don't look so scared. You're alive!" from The Girl with Bees in Her Hair. Copyright (C) 2004 by Eleanor Rand Wilner. Used with the permission of The Permissions Company, Inc., on behalf of Copper Canyon Press, www.coppercanyonpress.org.

“Trümmerfrauen," "Middle Class Vantage," "Facing into It," "On Ethnic Definitions," "Of a Sun She Can Remember," "The Messenger," and "Up Against It" from Reversing the Spell: New and Selected Poems. Copyright (C) 1998 by Eleanor Wilner. Used with the permission of The Permissions Company, Inc., on behalf of Copper Canyon Press, www.coppercanyonpress.org.

Several poems originally appeared in Tourist in Hell, Otherwise, Sarah's Choice, and Shekhinah by Eleanor Wilner. (C) The University of Chicago. Reprinted by permission. Tourist in Hell: "History as Crescent Moon," "Magnificat," "In a Time of War," "The Show Must Go On," "Establishment," "Saturday Night," "Encounter at the Local Pub," "What Loves, Takes Away," "Voices from the Labyrinth: Minos, Ariadne, Daedalus, Minotaur." Otherwise: "Night Fishing in the Sound," "The Muse," "The Bird in the Laurel's Song," "Rhapsody, with Rain," "Being as I was, How Could I Help...?," Ume: Plum," "Bat Cave.” Sarah's Choice: "Reading the Bible Backwards," "Sarah's Choice," "Miriam's Song," "Classical Proportions of the Heart," "Conversation with a Japanese Student," "High Noon at Los Alamos," "The Last Man," "Postscript." Shekinah: "Emigration," "Without Regret," "Ars Poetica," “The World Is Not a Meditation," "Labyrinth," "In Medias Res," "The Fourth David: I. Donatello 1430-32: 62 1/4” II. Michelangelo 1501-04: 13'5”; III. Bernini 1623: life-size; IV. Anonymous 1979," "In Medias Res," "Ex Libris."

Editorial: Anne Savarese and Thalia Leaf

Production Editorial: Ellen Foos

Text Design: Pamela L. Schnitter

Jacket/Cover Design: Pamela L. Schnitter

Production: Merli Guerra

Publicity: Jodi Price and Keira Andrews

Copyeditor: Jodi Beder

Jacket/Cover Credit: Naoya Hatakeyama, River Shadow \#79,

from the River Series, 2002.

This book has been composed in Adobe Garamond Pro and Scala Sans

Printed on acid-free paper. $\infty$

Printed in the United States of America

$\begin{array}{llllllllll}10 & 9 & 8 & 7 & 6 & 5 & 4 & 3 & 2 & 1\end{array}$ 
To the continuing presence of

CLAUDIA EMERSON（I957-20I4）

MICHELLE BOISSEAU (I955-20 I 7)

TONY HOAGLAND (I953-20I8) 
